\title{
Disrupting the Gender Institution Consciousness-Raising in the Cocoa Value Chain
}

McCarthy, Lauren; Moon, Jeremy

Document Version

Accepted author manuscript

Published in:

Organization Studies

DOI:

$10.1177 / 0170840618787358$

Publication date:

2018

License

Unspecified

Citation for published version (APA):

McCarthy, L., \& Moon, J. (2018). Disrupting the Gender Institution: Consciousness-Raising in the Cocoa Value Chain. Organization Studies, 39(9), 1153-1177. https://doi.org/10.1177/0170840618787358

Link to publication in CBS Research Portal

\section{General rights}

Copyright and moral rights for the publications made accessible in the public portal are retained by the authors and/or other copyright owners and it is a condition of accessing publications that users recognise and abide by the legal requirements associated with these rights.

Take down policy

If you believe that this document breaches copyright please contact us (research.lib@cbs.dk) providing details, and we will remove access to the work immediately and investigate your claim. 


\section{Disrupting the Gender Institution: Consciousness-Raising in the Cocoa Value Chain Lauren McCarthy and Jeremy Moon}

Journal article (Accepted manuscript* )

\section{Please cite this article as:}

McCarthy, L., \& Moon, J. (2018). Disrupting the Gender Institution: Consciousness-Raising in the Cocoa Value Chain. Organization Studies, 39(9), 1153-1177. 001: 10.1177/0170840618787358

\section{DOl: https://doi.org/10.1177/0170840618787358}

Copyright (C) The Author(s) २०18. Reprinted by permission of SAGE Publications.

* This version of the article has been accepted for publication and undergone full peer review but has not been through the copyediting, typesetting, pagination and proofreading process, which may lead to differences between this version and the publisher's final version AKA Version of Record.

Uploaded to CBS Research Portal: July २०19 
Disrupting the gender institution: Consciousness-raising in the cocoa value chain ${ }^{1}$

Lauren McCarthy

\author{
Royal Holloway, University of London \\ and
}

Jeremy Moon

Copenhagen Business School

\begin{abstract}
Gender is one of the most taken-for-granted institutions. Inequality is a common by-product of this institution and questions arise as to how such inequalities can be addressed. We uncover the cognitive and emotional processes individuals experience that enable them to begin disrupting the gender institution, within our case context of a gender equality programme in the Ghanaian cocoa value chain. We identify four elements of institutional apprehension: theorising, auditing, relating to others and exploring difference. These processes help individuals 'see' the dimensions of the gender institution: its order's laws and rules, its organisational gender regimes, and its gendered practices in daily interactions. Furthermore, some individuals are able to appreciate the dynamic interplay between these dimensions, and the power relations that are inherent within them. We argue that this fifth element of institutional apprehension, consciousness-raising, is particularly important for achieving equality. Consciousnessraising involves connecting everyday practices with organisational and structural rules, thus making 'the personal political'. It enables individuals to re-consider the way that power plays out in relational ways within value chains, promoting variously fatalism, resistance and the possibility of more multi-dimensional solutions to gender inequality.
\end{abstract}

\title{
Keywords
}

Institutional work, gender inequality, gender institution, global value chains, consciousness-raising.

\section{Introduction}

\footnotetext{
${ }^{1}$ This is the accepted, pre-proof version of McCarthy, L. \& Moon, J. (2018). Disrupting the gender institution: Consciousness-raising in the cocoa value chain, Organization Studies, 39(9): 1153-1177. $\underline{10.1177 / 0170840618787358}$
} 
Institutions are "stable, valued, recurring patterns of behaviour" (Huntington, 1968, p.12), but they are also liable to change (Lorber, 1994; Walby, 1997). Inequalities can be understood as by-products of institutionalisation (Lorber, 1994). We focus on a specific and entrenched inequality: gender; in the context of a Fairtrade value chain with the purpose of exploring how individuals in this organisational field may recognise and challenge gender inequality.

Gender equality is enshrined in the UN Declaration of Human Rights and is written into many national laws. Yet despite decades of feminist activism (Walby, 1997), and evidence of relevant organisational learning and development (Rao et al., 2016), gender inequality persists. Women's access to education, employment and security remain unequal to that of men in many countries (World Bank, 2011). Despite more women entering the workplace and holding positions of decision-making (Walby, 1997), patterns of gendered power within organisations and wider society have not been recalibrated (Calás, Smircich \& Holvino, 2014). For example, when women do enter the labour market it is often for part-time, lower-paid and insecure work (World Bank, 2011), especially in (but certainly not limited to) the global South. Thus, the fight for gender equality continues as gender inequalities are recreated, especially in corporate value chains (UN Women, 2015).

Paradoxically, perhaps, value chains are increasingly sites of efforts to rectify inequality (Grosser, McCarthy \& Kilgour, 2016), often through partnerships between different forms of organisation (Prügl \& True, 2014). Yet in organisation studies the context of value chains for institutions and inequality remains under-studied (Acker, 2004). Our case features a British confectioner, a Ghanaian cocoa cooperative, their NGO partner, and smallholder cocoa farmers, who have worked together on gender inequality in the cocoa value chain since the mid1990s but have experienced disappointingly slow progress.

Studies of gender inequality in organisations largely portray the persistence of inequality (Deutsch, 2007; Benschop \& Verloo, 2011), and solutions are usually targeted at structural or policy levels, for example through diversity policies or anti-discrimination laws (Ely \& Meyerson, 2000; Waylen, 2014). Adopting a social constructionist feminist approach to gender, Lorber (1994) reveals problems in focusing on structural elements of inequality. Instead the gender institution (Connell, 1987; Lorber, 1994; Risman, 2004; Yancey Martin, 2004) is conceived as a multi-dimensional phenomenon within which gendered practices, regimes and an order create inequalities by constructing difference between men and women. Less is known about how people might "undo" (Deutsch, 2007) or "dismantle" (Lorber, 1994) gender inequality, and empirical studies on all dimensions of the gender institution are rare. 
The institutional work literature offers some suggestions. Institutional work is the purposive action that individuals undertake to create, maintain or disrupt institutions (Lawrence \& Suddaby, 2006). Recent studies demonstrate that cognitive (Suddaby, Viale \& Gendron, 2016) and emotional (Voronov \& Weber, 2016) processes are important antecedents for disruptive institutional work (Suddaby et al., 2016). Voronov and Yorks (2015) theorise these processes as "institutional apprehension". Yet it is unclear what apprehension is required when the institution under question is as embedded and immutable as gender. This reflects how power has been relatively neglected within empirical studies of institutional work (Lawrence, 2008; Lawrence, Leca \& Zilber, 2013; Munir, 2015). Institutions are often described as being 'taken-for-granted' (Oliver, 1992) and it is this taken-for-grantedness which, we argue, is a manifestation of gendered power relations.

We offer three contributions to the study of institutions, gender inequality and organisations. First, by conceptualising gender as a multi-dimensional social institution, and empirically exploring its dimensions and their interactions, we contribute to better understanding of gender equality efforts in organisations. Second, we empirically identify 'theorising', 'auditing', 'relating to others' and 'exploring difference' as elements of institutional apprehension, each relevant to different dimensions of the gender institution: its order, regimes and gendered practices. This reinforces the importance of conceptualising and studying institutions as multi-dimensional entities. Third, we identify consciousness-raising (CR) as a fifth form of institutional apprehension, critical for addressing gender inequality. Consciousness-raising involves individuals appreciating the dynamic interplay between dimensions of the institution, and how this interplay replicates inequality. This helps individuals consider power as relational, rather than only distributional. If power is everywhere and held by everyone (Foucault, 1977), then the possibilities for destabilising gendered power relations may increase. This provokes some individuals into institutional work: purposive attempts to disrupt the gender institution, typically by addressing inequality not just at structural levels, but through everyday practices. In this way we contribute to existing studies of cognitive and emotional institutional work by showing how individuals, through consciousness-raising, may (or may not) begin to act on inequalities in organisations.

We first introduce the concept of gender as an institution and its relationship to inequality, and the concept of institutional apprehension. We present our case study and methods. We explore the four elements of institutional apprehension particularly important for challenging gender inequality, and present consciousness-raising as a key fifth synthesising element. We discuss these findings in relation to how they advance our understanding of gender 
inequality, institutions, and organisations.

\section{Gender inequality and the gender institution}

Organisational approaches to gender inequality tend to focus on the global North by addressing such issues as 'women on boards' (Grosser, Moon \& Nelson, 2017), and on structural solutions to inequality (Calás et al., 2014; Waylen, 2014). Yet, whilst policies and programmes proliferate, and more women move into decision-making roles, evidence suggests that the stereotypes and "descriptive beliefs" (Ridgeway \& Correll, 2004, p.527) about men and women's 'nature' remain relatively unchanged (Lueptow, Garovich-Szabo \& Lueptow, 2001). These attitudes are partially accounted for by interactions: including language, talk and action (Connell, 1987; Ridgeway \& SmithLovin, 1999; West \& Zimmerman, 1987). Whilst studies into organisations and inequality continue to explore institutional reform in the form of structural changes (Elvira \& Graham, 2002), they suggest partial solutions to partial problems (Calás et al., 2014). Gender inequality exists in vertically embedded relations between macro and micro phenomena (Connell, 1987), and it is in this relationship that gendered power relations persist (Connell, 2009), cutting across other institutions such as race, management and the family (Acker, 2006). Our argument is that for organisations, and the individuals within them, to challenge gender inequality, it is necessary for them to see the multi-dimensional gender institution.

Gender is an institution in that it is an entrenched, historical, ideological and embodied omnipresent part of social (and thus organisational) life (Lorber, 1994; Yancey Martin, 2004). The utility of conceptualising gender as an institution is in recognising that it reproduces itself but can be challenged (Connell, 2009; 1987; Yancey Martin, 2004 - Figure 1). At the macro level is the "gender order", "the structural context of particular relationships and individual practices" (Connell, 2005, p. 6); discernible in tangible policy and regulations such as marital law and in intangible cultural mores, such as heteronormativity associated with marriage. At the meso level are "gender regimes" (Connell, 1987), found within organisations (Acker, 1992; 1994). A "regime" is "the patterning" of gender relations which feeds up into the gender order and down into everyday practices, in a dynamic flow of social construction (Connell, 1987). "Patterning" can be tangible (such as parental leave allowances) (Acker, 1990; 1992; 1994) or intangible (in expectations, unwritten rules, symbols) (Acker, 1992; Gherardi, 1994). 
Figure 1

At the micro level, the "engine room" of institutionalisation (Schwalbe et al., 2000), are gendered practices (Acker, 1992; Lorber, 1994). "Practice" includes talk, text, interaction and action (Bourdieu, 2001; Connell, 2009): the gender "we think and do in everyday life" (Gherardi, 1994). For many theorists, practice has been the entry-point to explore why gender inequalities persist in organisations (Acker, 1992; Benschop \& Dooreward, 1998). Less is known about how individuals' practices, especially the cognitive and emotional processes that go alongside these, might enact change on the gender institution and promote equality (Benschop \& Verloo, 2011; Deutsch, 2007). We propose that institutional work theories, particularly those focusing on the cognitive and emotional precursors to change, may help gender theorists move from a focus on how inequalities are maintained, to the un/successful 'work' people do to redress gender inequality.

\section{Institutional work and apprehension}

Institutional work focuses on how individuals might actively engage in disrupting social institutions (Lawrence \& Suddaby, 2006; Lawrence, Suddaby \& Leca, 2009; Lawrence et al., 2013), and is a useful theory because it recognises that institutions, such as gender, are not only monolithic structures but also socially-constructed in everyday practice (Lawrence \& Suddaby, 2006). Thus outcomes associated with institutions, like inequalities, are maintained by individuals, but could also be disrupted by them. Lawrence and Suddaby (2006, p.217) define disruptive institutional work as the "tearing down" or "rendering" of institutions as ineffectual. Institutional contradictions, "ruptures and inconsistencies both among and within established social arrangements" (Seo \& Creed, 2002, p.225) are identified as crucial initial processes in institutional disruption (Creed, de Jordy \& Lok, 2010; Greenwood, Suddaby \& Hinings, 2002), including within studies of gender and institutional change (Karam \& Jamali, 2013).

The question remains, how might individuals begin to perceive "institutional contradictions" to engage in disruptive institutional work (Nielsson, 2015; Voronov \& Yorks, 2015; Voronov \& Weber, 2016)? Recent literature explores the cognitive (Gondo \& Amis, 2013; Suddaby et al., 2016), emotional (Creed et al., 2010; Creed, Hudson, Okhuysen \& Smith-Crowe, 2014; Friedland, 2017; Moisander, Hirsto \& Fahy, 2016; Ruebottom \& Auster, 2017; Voronov \& Vince, 2012), and individual-level drivers of, or antecedents for institutional work. Voronov \& Yorks (2015) collapse affective (emotions) and cognitive (thinking) processes to conceptualise "institutional 
apprehension". We adopt this concept to examine the micro-level processes underscoring individuals' efforts to change the gender institution (Powell \& Colyvas, 2008 - see also Creed et al. 2010; Moisanser et al., 2016; Suddaby et al. 2016). What "may facilitate a change in individuals' consciousness such that the relative dominance of some institutional arrangements is no longer seen as inevitable?" (Seo \& Creed, 2002, p.233).

Power relations permeate gender and reside in the everyday gendered ideologies, practices and thought, where power is not 'held' but 'relational' (Connell, 1987; 2009; Foucault, 1977). Yet power in this form has not featured in institutional work studies (Lawrence et al., 2013; Lawrence, 2008; Munir, 2015). When power is mentioned, it is usually considered as “distributional” (Levy \& Scully, 2007). Within individual-level approaches to institutional work, power is largely conceptualised as “disciplinary or judicial” (Creed et al., 2010; Voronov \& Weber, 2016) and "episodic" (Moisander et al., 2016, p.967 drawing on Lawrence, 2008). A gender lens forces us to move beyond these forms of power (Kenny, 2007).

If disruptive institutional work can only begin as individuals "apprehend" (Voronov \& Yorks, 2015) "their own shared embeddedness: within large-scale, "powerful” institutions (Nielsson, 2015, p.373), how is gender equality possible? The gender institution presents the problem of “embedded agency” (Battilana and D'Aunno, 2009) par excellence.

\section{Research context and design}

A three years qualitative case study of a gender equality programme within the Fairtrade cocoa value chain was undertaken by Author 1 and reviewed Author 2. The programme is a joint initiative between a small UK-based Fairtrade confectioner, Braithwaite's Chocolate Company (BCC); the Ghanaian cooperative from which it has long sourced cocoa, Adwenkor, certified by the Fairtrade Labelling Organisation (FLO); and BCC's partner NGO, TradeFare, which offers advice and evaluations to BCC and Adwenkor (Figure 2). ${ }^{2}$

Figure 2

\footnotetext{
${ }^{2}$ Pseudonyms are used for the organisations. Interviewees are identified by their organisation, job role and number. For example, BCC1 (Braithwaite's Chocolate Company Interviewee 1), AD4 (Adwenkor Interviewee 4), TF2 (TradeFare Interviewee 2). Identifiers and job positions are listed in Table 2.
} 
Braithwaite's Women for Women Programme

In the mid-1990s BCC and Adwenkor launched the Women for Women Programme (WFWP) to address women farmer's economic inequality, and under-representation in the cooperative and its decision-making structure (Table 1). The WFWP is known for its 'good practice' in the value chain literature (External Docs, 2004-2014). ${ }^{3}$ Our research, however, took place in light of a 2013 internal evaluation, which revealed a number of problems (Table 1).

Table 1

\section{Data collection}

Different research methods (in-depth interviews, documentary analysis, observations and focus group data generation) were employed (Table 2) to enable close access to individuals' talk, thoughts, feelings and actions. Data collection took place during Author 1's field trips to Ghana in 2013 and 2016 to interview staff, observe meetings, visit smallholder farms, conduct focus group discussions with farmers and have informal conversations with staff at Adwenkor. Between these trips, data were gathered through follow-up phone calls and London-based meetings with BCC and TradeFare.

Table 2

Interviews. Twenty in-depth interviews were conducted with individuals from BCC; Adwenkor and TradeFare (Table 2). Interviewees were chosen because of their connection with the WFWP and their diverse organisational functions. Interviewees could explain, narrate and reflect on their roles in the WFWP, and on their understanding of 'gender' and 'equality'. Guiding questions focused interviews, but interviewees were encouraged to introduce themes they believed relevant. This focus on language and narratives is crucial for the study of gender and institutional work which necessitates uncovering meanings and practices (Lawrence et al., 2009). Interviews (45 -

\footnotetext{
${ }^{3}$ In 2013 we found 14 academic peer-reviewed articles featuring the WFWP; 13 NGO reports featuring WFWP-based case studies; and 93 English language newspaper reports mentioning the WFWP.
} 
120 minutes) were in English, except one in Twi aided by a translator. They were voice-recorded and professionally transcribed.

Observations. Author 1 was an authorised non-participant observer of WFWP meetings in the UK and Ghana. They were also a non-participant observer at public events alongside key informants. The two Ghana field-trips allowed observations of staff-farmer interactions. Author 1 took handwritten notes of the meetings, individuals' interactions, and what was said. Approximately 260 hours of observations were typed up for data analysis.

Focus Group Data. Author 1 held four three hour workshops with farmers in 2013 and in 2016. These involved the generation of visual data in the form of drawn diagrams (Author 1, 2016) and focus group discussions (FGDs). They were attended by between 6 and 20 cocoa farmers $(n=152)$, exploring their roles in cocoa production, income streams, decision-making ability, and domestic workloads (Author 1, 2016; Author 1, forthcoming). Men's and women's sub-FGDs allowed participants to explore their experiences with people of their own sex, before sharing thoughts in plenary. FGDs were videoed, translated and transcribed for analysis. Visual data were coded through systematic content analysis.

Documents. 17 WFWP internal documents (policies, memos, unpublished reports) were accessed through its archives. External documents (independent NGO research, academic evaluations, newspaper reports) were found through online search engines and 'Lexis Nexus'. 34 WFWP external documents (blogs, website content, press releases, annual reports) were also analysed. 171 documents helped to contextualise, frame, and triangulate the verbal and visual data.

\section{Data analysis}

The data collection process was iterative, with Author 1 beginning analysis and shaping future interview questions during data collection, enabling analysis to occur in feedback loops (Langley, 1999). Data were initially coded manually and then by NVivo10 computer software. Authors 1 and 2 reviewed codes using a process approach (Gioia, Corley \& Hamilton, 2012; Figure 3). Initial coding focused on emergent issues pertaining to our research question, and as captured in interviewees' own in vivo codes. This long list of codes was re-grouped into first-order 
concepts, by "seeking similarities and differences among the many categories" (Gioia et al., 2012, p.20) whilst keeping close to participants' own wording. Second-order themes informed by institutional work and gender theory began to emerge reflecting common phrases from the literature such as 'theorising' (Greenwood et al., 2002; Mena \& Suddaby, 2016). Other second-order themes, such as 'relating to others' and 'exploring difference', emerged organically. Finally, we examined how these themes relate to each other, particularly in their intention and intended audience. This enabled us to theorise the different elements of institutional apprehension pertaining to particular dimensions of the gender institution.

Figure 3

We then revisited the data for an abductive round of coding (Alvesson \& Kärreman, 2007), allowing more abstract theoretical concepts to be derived from the initial data (Langley, 1999). This informed our theorisation on the connections between the elements of institutional apprehension, giving rise to the concept of consciousness-raising as a critical antecedent to the disruption of the gender institution, and the inequality therein.

\section{Findings: Elements of apprehension of the gender institution}

In the context of an ailing gender equality programme, individuals needed to reinvigorate their efforts to challenge gender inequality. Like Voronov and Yorks (2015), we found important cognitive and emotional processes which preceded such action. Our first key findings show different elements of the apprehension of the gender institution, enabling individuals to 'see' and 'feel' its different dimensions. We show how 'theorising' enabled individuals to

'see' the gender order, the macro dimensions of the gender institution. The gender regime (the meso dimension) was apprehended through 'auditing'. Gender practices (the micro dimension) were revealed as individuals 'relate to others' and 'see difference'. Whilst some of these elements feature in the institutional work literature, we reiterate their salience, and highlight their distinctiveness in the context of embedded, power-laden institutions such as gender. Our second key finding is the identification of a fifth element of institutional apprehension, 'consciousnessraising', in which individuals understand the dynamic interplay between the different dimensions of the gender 
institution (Figure 1), chiefly through the exposition of power relations. Individuals can then respond with increased activism, resistance or fatalism.

\section{Theorising ('Seeing' the gender order)}

Our first element of institutional apprehension relevant to disrupting the gender institution is 'theorising', identified as important in institutional change, as individuals debate and theorise change to professions (Greenwood et al., 2002) and to CSR standards (Mena \& Suddaby, 2016). We relate 'theorising' to individuals 'seeing' the gender order of the gender institution, by explicating the gender inequality within field-level rules, regulations and laws (Connell, 1987; 2009). and their aims: 'What is it that we want to achieve? What does empowerment look like? I'm asking myself, for what? For what ends?' (TF1).

British and Ghanaian participants began to see that rules and regulations were gendered ('the setup in this country is not favourable to females' AD8), and theorised how this related to land ownership. Land ownership is a prerequisite to membership of the Fairtrade cooperative which perpetuates gender inequality since women are unlikely to own land (Table 1): 'I think that one of the criticisms that's levelled at Fair Trade is that you're not reaching the poorest of the poor, who are often women, because in order to get your Fair Trade certificate you have to reach certain standards [in land ownership]' (TF1). Fair Trade governance was preventing change: 'There is a 'gaping hole' in Fairtrade's narrative about the role of women in agricultural commodities since women's empowerment was removed as a core standard and replaced with a general standard about discrimination' (Internal document, 2014).

Quotas, conversely, were an ostensibly pro-equality 'gendered rule', designed to address norms around women's leadership: 'The president [of the cooperative committee] is a woman... it has been seen as a job of men. That is a perception. We know this and to address [it], we try to preserve some of these positions for women' (AD2). Yet other individuals theorised that the quota ('the rules' as many participants named it) was limiting gender equality efforts: 'The onlookers said "oh cool, the statistics are great", especially when you compare with those other commodities. $29 \%$ of Adwenkor members are women, or whatever... and I think institutionally the rules were not helpful' (TF5).

In sum, individuals in the three organisations theorised the role of regulations (for Fair trade governance and cooperative membership) as well as 'rules' (like quotas) in exacerbating gender inequality in the cocoa value 
chain. In so doing, the gendered 'order of things' became more obvious to them, which we argue is one element in the apprehension of the gender institution.

\section{Auditing ('Seeing' the gender regime)}

The gender regime consists of intangible and tangible rules and norms found within organisations (Acker, 1992). We find that individuals 'audit' as an element of institutional apprehension. They qualitatively, and often emotionally, systematically review and account for organisational assumptions, decisions and programmes on gender equality. Accordingly, individuals 'see' the gender regime within their organisations, and begin to apprehend their own (and others') embeddedness in such regimes.

First, individuals 'audited' the WFWP's focus on alternative income training as a means of challenging gender inequality, rather than 'helping women become better farmers' (TF4). This echoes the WFWP evaluation's conclusion that women were making little to no income from such projects (Table 1). This meant gender inequality was not addressed, as women farmers remained marginalised in the cocoa economy:

I think the best thing Adwenkor can do is to actually get Adwenkor women and men farmers to be as efficient and effective as they can be, being cocoa farmers. That's their commonality! So if you could get them to increase their yield, and earn more income, that's the thing you can most - presumably -affect (BCC1).

Relatedly, there was a concern about how 'empowerment' was translated into programmatic design. Was empowerment 'about income: if you give me a car with no petrol, how will I run?' (AD7); or 'about the mind?' (AD5). Auditing WFWP's aims and methods, TFI became frustrated with her Ghanaian colleagues:

I have lots of round and round conversations that it's not enough to just go and spend half a day with a group of people and lecture them about why it's important to take up leadership positions... You know, there's a whole set of circumstances that affect whether a woman is able, or wants even, to put herself forwards for that leadership position... We need to understand and then show others what those circumstances might be (TF1).

Further, individuals reviewed the historic under-resourcing and shirking of responsibility of the WFWP: 'It's nobody's business' (AD4). The gender officer, AD4, was left to manage the original programme alone, being 
'given a lot of responsibility with none of the clout to make it happen' (TF3); 'The board members go out and make a lot out of 'now we have women leaders... we do this, blah blah', they say, but meanwhile they don't make any provisions for all those promises' (AD8). Board member TF4 summarised how the gender regime at Adwenkor and BCC paid the WFWP 'lip-service' because 'the gender consequences of rule-making were not internalised' (TF4). Auditing also involved counting the number of women and their roles across all the organisations, not just farms, where the WFWP was based. Within Adwenkor:

\footnotetext{
We used to have a team of research and development officers that were there to do training....and they had a mix of men and women. Over time... we've ended up with young men who are good on computers. What does that say from a role model perspective?' (AD2).
}

Expanding on this criticism, TF1 sighed: ‘it almost feels like when we're talking about gender and women's empowerment we're always talking about the farmers, but it's not. It needs to cut through everything that we do'. She then expounded on Adwenkor's 'big man' (TF1) culture, reflecting on the gendered and embodied cultural expectations of being a leader:

\footnotetext{
I found it slightly infuriating... it [WFWP leadership training] is kind of not looking at people directly and being very distant... But that's what Ghanaian culture, or at least Ashanti culture, demands. That you're a "big man" and you look very stern and you don't connect with people and you actually rarely speak directly, you speak through your representative (TF1).
}

Thus, auditing enabled individuals to start to understand some of the complexities of fighting gender inequality by revealing the less-well-known 'gender regimes' (Connell, 2009) at play within the organisation of the cocoa value chain. For example, as individuals reflected on organisational failings they audited the formal hierarchy of the programme (characterised by a lack of support and management strategy), but they also questioned the informal 'big man culture' at Adwenkor (TF1). Thus, the gender regimes of organisations (tangible and less tangible), and the concurrent inequalities, were apprehended.

Relating to Others and Exploring Difference ('Seeing' gender practices) 
Gender practices are the interactions, performances, talk and action we all 'do' everyday (West \& Zimmerman, 1987). We identify two further, related, elements of institutional apprehension that helped individuals 'see' gender practices: Relating to Others and Exploring Difference.

Relating to Others. British interviewees, who when discussing gender inequality in Ghana, would tell gender-related anecdotes from other contexts. 'Relating to others' in this way is useful for institutional apprehension of gendered practices as it translates very different experiences (living in Ghana versus the UK; being a manager or a farmer) into empathetic situations. Examples included reflecting on being a woman in a male-dominated political party (BCC1), or on a board (TF4), the division of labour in one's own kitchen (BCC4, TF3, AD4) and sexism in the workplace (AD5). One prop for doing this was popular media:

\footnotetext{
Have you seen 'Made in Dagenham' [a popular film]?... I watched it the other week... The first thing I did was go out and buy it, because I want my daughter and I want my girlfriend's daughter to see it, 'cos I want girls whose lives I can influence, not to take anything sitting down. To stand up and to challenge and to know...to recognise that she doesn't have to just accept the situation and that she can challenge it and that hopefully in the end right will win out. And equality will out (BCC4).
}

So presumably you've read Lean In [Sheryl Sandberg's book]? There's definitely some truisms in it...you can't help but agree with her that even here there is still, an unconsciously embedded gender bias in business or indeed everything that we do, and that's in $u s$ as much as it is in men. So if you think that's here, then think how much that must be the case in Adwenkor, and so even the women leaders and the people who are responsible for the gender programme will be saying "women should be this, and women should be that"... So... there's a gap between where we and BCC are, and where Adwenkor is, in terms of what their vision for gender equality is I suppose. And maybe that is a problem, and maybe that bridge is really difficult to cross (TF1).

In these exchanges BCC4 (a man) and TF1 (a woman) use cultural references as a means to further understand gender practices. Numerous participants in both countries, like BCC4, reflected on gender inequality through the eyes of parenthood, often becoming upset. The film Made in Dagenham becomes the vehicle for BCC4 to passionately articulate his view on what gender equality means: the ability for women and girls to 'stand up and to challenge and to know'. Lean In is used by TF1 to compare British and Ghanaian men and women's capacity for 
implicit bias. Importantly, whilst she starts by reflecting on this as cross-cultural, she ends by stressing cultural difference, and dejectedly concludes that this is why inequalities persist. This underlies the paradox regarding 'relating to others', in that often this includes stressing the 'otherness' of the Other. We call this 'exploring difference'.

Exploring Difference. For some, recognising difference in women and men's everyday experiences was important for understanding gender inequality's persistence:

\footnotetext{
You see, here in our part of the world - now I think of it, its men who... We both work, but as a man, I'll have acquired the land, but it's both of us [men and women], tilling the land. But when the income comes, it's the man who is managing it (AD8).
}

The exclusive focus on women within the WFWP, AD8 continued, was a problem, and equality efforts that ignored patriarchal attitudes were in his opinion ineffective (see Table 3).

Being part of the evaluation and visiting female farmers helped AD4 'learn new things', admitting 'I wasn't expecting them to be that smart... but they know what they are about. You cannot like, force things on them... I learned that with a little help, the women could do marvellous things'. Here AD4 explores the differences between herself and the farming women she works with, considering her relative privilege and her assumptions about gender and class, since as a middle-class Adwenkor employee she had a very different perspective on gender than other women in the value chain.

Within focus groups, farmers discussed the different farm roles men and women performed and their equity. Some men saw 'difference' in recognising that women 'do double work' (farming and household), admitting that 'when...both of us arrive home from the farm, we should help' (Men's FGD4, Western Region, 2013). Whilst some women welcomed these sentiments (Women's FGD2, Ashanti Region, 2013), others angrily demanded 'wages for housework':

\footnotetext{
Men might wish to help at home but our culture is such that the women should do the house chores, so men stay away from helping, because if people see then they can take them to task and say you are a fool or... Because our society says that the women should do house chores, then they [men] should give up more money so that will compensate! (Women's FGD3, Western Region, 2016).
} 
Here the women farmers recognise 'differences' in the domestic division of labour as a social construct, and the social norms which apparently stop men from contributing to this work. These comments, although varying in optimism, indicate that some women and men may be able to challenge inequality through understanding how certain everyday practices, such as housework, are gendered.

Conversely, 'exploring difference' showed just how ingrained some practices are, and how they hide power relations. A frequent example of gender practices' hidden dimensions impacting on equality efforts was cooking. Farmers, male and female, expressed horror and amusement at the prospect of men undertaking responsibility for cooking the evening meal (Observations 2 \& 5, Western \& Ashanti Regions, 2013), because in Ghana this task is closely connected to notions of femininity and marriage (Clark, 1994). Cooking can take many hours, requiring trips to wells and markets. Our visual data revealed that many women spent most of their time cooking, to the detriment of other daily activities (Author 1, forthcoming). Farmer focus groups sometimes used cooking and childcare tasks to emphasise that men and women were 'not the same' (AD1) in nature: 'Some of the women, when you give them money their status changes, they want to become the boss in the house. In our society we don't like that. We think that they should still be calm' (Men’s FGD3, Western Region, 2016). 'Exploring difference' can thus emphasise the stratification between men and women, and can contribute to reifying and maintaining inequality in the gender institution (Schwalbe et al., 2000).

Linking it all up: Consciousness-Raising. We have thus far identified four elements of institutional apprehension which raise questions for individuals around gender inequality in the cocoa value chain, and have shown how they relate to 'seeing' and 'feeling' different dimensions of the gender institution. But how might these apprehensions lead to institutional work? What helps individuals make the leap from apprehension to action? Our data suggest that one factor is an apprehension of the dynamic interplay between the dimensions of the gender institution, where overt and covert gendered power relations play out, and which underlie persistent gender inequality. We call this apprehension 'consciousness-raising'.

Consciousness-raising (CR) has been described as a "rhetorical strategy utilized extensively by feminists in the 1970 s to give voice to women's experiences" (Sowards \& Renegar, 2004, p.535), typically through meeting in small groups, giving personal testimonies, and generalising personal experiences to wider social structures and 
inequality (Sarachild, 1978). ${ }^{4}$ Twenty-first century, feminist consciousness-raising has developed in four keys ways: it has introduced wider diversity issues; it frequently occurs through shared experiences through media (the Internet, books, films); it includes men's consciousness-raising; and it does not necessarily aim for physical action (Sowards \& Renegar, 2004). Reger (2004, p.212) thus identifies CR as the "intersection of the personal and the political" and as a "cognitive technique" of emotion work, as it encourages individuals to attend to their emotions (such as anger, shame, frustration) by understanding that gender inequality is not a result of individual failings, thus potentially spurring them into activism (Reger, 2004, drawing on Hochschild, 1979, p.562). We argue that this description reflects how some individuals in organisations could not only apprehend the different dimensions of the gender institution through the processes we have outlined, but also see how these dimensions relate to one another- chiefly through a consideration of gendered power relations. It is this synthesis which we identify as CR. Echoing Reger (2004), CR was often emotional for individuals, with participants either responding passionately, angrily, or sadly within interviews, or recounting emotions during their testimony. We theorise that CR enabled some individuals to engage in disruptive institutional work aimed at fighting gender inequality in the cocoa value chain. Others, however, did not appear to engage further. We provide examples below, and in Table 3.

Table 3

At first, BCC4 saw equality as 'equal opportunities', and focused on quotas as a means of instigating new rules that would challenge the regulatory components of the tangible gender order. Yet he began to muse upon the nature of equality by relating the Ghanaian situation to what he wanted his daughter to learn after watching a film. This process of 'relating' showed how he recast gender equality as equivalent to women and girls' voice and 'challenge', related to micro-level change, and not just to policy changes. This also entailed a new understanding of inequality lying not just in men's 'power over' women through regulatory structures akin to a one-dimensional visible form of power (Lukes, 1974), but also how organisational regimes and everyday practices are sites of

\footnotetext{
4 Feminist, civil rights and LGBT groups use the term CR to refer to the sharing of personal stories in groups, in order to reflect on wider power relations (Ryan, 2013). Within pedagogy, Freire (1972, p.27) built on Marxist theory to develop the idea of 'conscientization', a process of individuals seeing themselves "as knowing subjects, achieve a deepening awareness both of the socio-historical reality which shapes their lives and of their capacity to transform that reality" (Freire, 1972, p.27). These approaches both link the personal with the societal to elicit power relations, in order to affect social change.
} 
gendered 'covert power' (Lukes, 1974). Women, however, are not just 'powerless' within patriarchal structures, but have their own agency and 'power to' (DiMaggio, 1988) succeed through voice and opportunity. BCC4 saw that he could not use his privilege to 'fix' the gender institution himself (though quotas), but that women like his daughter, and farmers in the cocoa value chain, were agentic too. So, understandings of power, and how this relates to gender inequality.

Similarly, 'exploring difference' in farmers' household roles (gender practices) enabled individuals to connect the gender regime, and programmatic failings (such as low quality of craft products) with the wider gender order: 'We see that, if a person is not empowered at home... no matter how much money you give a person they are going to need more' (AD1), meaning that 'we have to sensitise our farmers, when we meet them, one on one' (AD2) and 'orient their minds' (AD5). Gender literacy and sensitisation workshops, explained AD5, which focused on more equitable household relations, were crucial to the organisation:

You know, as women, we talk, we socialise, we make the world less serious... Women hold up the community, they hold society together. As you work with the women, everything starts flaming up. Because they are the fuel, the ones that flame the cooperative up (AD5).

This echoes the understanding that equality is achieved not just through economic approaches to inequality, but through everyday practices (including talking and socialising) that can aid confidence and social solidarity. Consciousness-raising enables the "personal to become political" (Hanisch, 2006), it means "becoming aware of things you did not notice or accepted without considering how such assumptions or practices came to be, and especially not questioning who benefited from these practices" (Ryan, 2013, p.1). In our case, it is not only women becoming aware of their own place within the gender institution, but both women and men becoming aware of gendered power relations for farmers, workers, staff, themselves: for everyone, in the cocoa value chain.

We therefore see consciousness-raising as a particularly important component of the fight against inequality, because for some individuals the process led to disruptive institutional work. For example, TF1 began petitioning Adwenkor, BCC and her own organisation for 'all-round organisational buy-in', 'really pushing' (TF1) for a new gender policy that would try to include women's specific needs: 'OK, why not rip it up and start again?' (TF4). Individuals at BCC and Adwenkor also saw that they needed to spend more time consulting farmers about their needs in their own contexts, so that they 'come up with new ideas, and understand the concepts' (AD8). A draft 
document stated that the WFWP needed to:

Create greater differentiation in programmes and services rather than taking a 'one size fits all' approach. Understand trends in needs amongst different farmer groups (by geography, gender, role in production etc.) and design services to suit these. Establishing regional hubs (perhaps beginning in Western region) could be a good way to get closer to members and start designing programmes in this way (Internal Document, 2014).

By 2016 these policy changes had been implemented, with initial regional hub-based activities re-focusing on local market opportunities as well as implementing literacy classes for women and men farmers- based on their own needs (Observations and interviews with staff, Ghana, 2016). Men were integrated into the programme, through literacy classes and repeat gender sensitisation trainings: 'We should meet the men alone somewhere. And let the men know that by helping their women, they are helping their own future' (AD8). Importantly, British participants such as BCC4 and BCC5 (Table 3) were supportive of these classes, helping secure funds. Initial observations of the new literacy classes (Observations, Ghana, 2016), and farmer testimony, suggest that women feel more able to challenge existing inequalities through further education:

\footnotetext{
If you are able to read, you don’t even need to ask anybody... It's basically to be able to be confident. So when such opportunity [to stand for farmer representative roles] presents itself, I will be able to take up such possibility (Female farmer, literacy project, 2016).
}

Consciousness-raising can help support marginalised individuals' agency directly, and by helping others with more power and privilege to understand better the needs for a bottom-up approach to change.

At the field-level, lobbying was widely seen as a crucial next step. TF4 engaged in meetings and networks to recapture the 'radical' nature of Fairtrade and to get a gender policy for FLO 'back on the table' (TF4). A draft report argued that 'as influential actors in the sector we should work together to lobby for the reinstatement of this standard' (Internal Document, 2014). In 2016 new research was launched by FLO to better understand gender inequality in Fairtrade value chains, with the aim of ensuring better attention to the issue (Personal email 
communication with FLO, 2016). In 2017 Fairtrade Foundation reviewed their impact, admitting that more work is needed on 'women's empowerment' (Fairtrade Foundation, 2017).

Consciousness-raising does not always lead to disruptive institutional work (within the time-frame of our collected data). We surmise that some individuals who experienced CR became overwhelmed and potentially fatalistic about structural and everyday inequalities:

\footnotetext{
By now my vision of gender equality is focused on the rather desperate need for people who are culturally and institutionally barred...for the chance to assert themselves, without terribly dire consequences... So I think my vision is much more mundane than it used to be... I've reasonably concluded that increasing income with trading will not deal with two-thirds of the problems that those women face, day to day. So in the end, that is a bit of a downer for Fair trade, and trade. I don't think increasing livelihoods... is an automatic... driver for equality. At all. I think having a framework helps, like laws, and rules... but with the nuts and bolts I'm more pessimistic (TF4).
}

TF4 explains how her vision for gender equality has become focused on everyday practices and 'the mundane'. She argues that the solutions to inequality will not be provided through economics ('trade') alone, thus problematising the WFWP's approach to women's empowerment. She also sees use in macro and meso level 'laws and rules' but is unsure how to challenge the everyday practices, 'the nuts and bolts' where she sees inequality residing. Similarly, TF5 argues that 'It's not just that you put a gender programme in place... The far more important part is the norms'. This is CR in that it connects the dimensions of the gender institution together, and challenges working myopically on one area, such as trade and livelihoods. There is also an understanding of the gendered power relations residing in the different dimensions of the gender institution: power is seen as an 'institutional', 'cultural', structural 'barring' of women. Yet there is also recognition of the power residing in everyday gendered practices, the 'nuts and bolts'. TF4, however, like AD8 (Table 3) is pessimistic about the potential for achieving equality through changing everyday practice.

Others experience CR but then resist this new knowledge, for example by returning to an economicsfocused approach to equality:

I'm interested in recognising this as a business. I don't really understand- this thing to do with what happens in households. I'm not sure how much you can affect that. Directly. But I think you can affect it indirectly by getting 
women to be in more powerful positions, getting more income of their own' (BCC1).

This is not to say that BCC1, a UK-based manager, didn't 'see' the importance of gendered practices (such as in the household) and how power resides therein, but that she could not see how a business organisation could affect this. Her desire is to continue to focus on the gender regime's status quo (for example, promoting women's income and position within the cooperative) rather than gendered inequality present in household practices, despite evidence that farming women were being 'held back' at this level. We explore what such findings contribute to gender and institutional theories, below.

\section{Discussion}

We set out to explore how individuals in organisations may challenge gender inequality in a value chain context. We were particularly interested in how institutional apprehension might play out when the institution is as taken-forgranted and power-laden as gender (Lorber, 1994). Part of the reason gender is such an ingrained institution (Ridgeway \& Smith-Lovin, 1999) is because interaction between those we perceive as 'men' and 'women' happens daily, in households, workplaces, and families: gender "goes home with you" (Ridgeway \& Correll, 2004, p.512). Gender thus becomes "a significant definer of self and other in all social relational contexts" (p.512), and the "self" and "other" can usually be split into two equally-sized groups (Ridgeway \& Smith-Lovin, 1999). Further, "talking about gender for most people is the equivalent of fish talking about water" (Lorber, 1994, p.13) and this "invisibility varies with the position of the beholder" (Acker, 2006, p.252; Bourdieu, 2001). Thus, it is harder for those not subject to gender discrimination and inequity to apprehend the depth and breadth of gender inequality. Added to this is the complexity of organisations operating across national and cultural borders.

Our first contribution is therefore to empirically demonstrate the salience of the concept of a gender institution for institutional and organisational theory. This feminist sociological concept offers much to scholars of institutions and organisations, since it captures the multiple dimensions of institutions in general, and the ways in which inequalities are ascribed to them (Lorber, 1994). Our paper develops a model for how individuals 'do gender', and how they might 'undo gender', thus presenting a view of institutions, their structures, and individuals' agency, in dynamic interplay. The concept demonstrates that in order to challenge inequalities attached to institutions, such as gender, race, and ethnicity, understanding how the dimensions of its orders, regimes and practices feed into each 
other is key. In particular, the understanding of human practice as a site of continuing inequality (Schwalbe et al., 2000), and potential change is crucial, since it is in the everyday interactions, assumptions and language where inequality resides, as well as at meso and macro levels. Thus, we contribute to understanding of inequality, institutions and organisations by showing how theories about, and proposed solutions to, inequality focused on organisational and national level policy change can only ever be partially successful. The messiness of human practice, and the cognitive and emotional processes alongside this, require further attention. This is especially the case with large-scale institutions such as gender.

This leads us to our second contribution. We extend current understanding of how institutional change happens by first empirically identifying four elements of "institutional apprehension" (Voronov \& Yorks, 2015) during which individuals' awareness of the dimensions of large-scale institutions, in our case gender, comes into being. Individuals engage in 'theorising', 'auditing', 'relating to others' and 'exploring difference' as elements of institutional apprehension relevant to the gender institution, and its attendant inequality. In so doing they explore dimensions of the 'gender order' (rules and regulations), the 'gender regime' (organisational 'ways of doing things'), and 'gendered practices' (everyday interaction, norms, roles etc.). This empirically supports recent work which points to the importance of individuals' cognitive and emotional processes during attempts at institutional change (Creed et al., 2010; Creed et al., 2014; Nielsson, 2015; Suddaby et al., 2016; Voronov \& Yorks, 2015; Voronov \& Vince, 2012; Voronov \& Weber, 2016). We contribute further to this literature by demonstrating the multi-dimensional nature of institutions (and inequality) and thus different elements of institutional apprehension relevant to these. We argue that this both offers a finer, more detailed view on how people "think about how they think" (Turner, 1987, p.102) with regard to inequalities, but also pushes organisational institutional theorists to return to the institution itself as a key concept (Nielsson, 2015). The identification of these forms of institutional effort are also important for scholars of inequality, because whilst we know that inequalities are a by-product of institutionalisation (Lorber, 1994) we know less about how individuals might go about challenging them in organisational life (Deutsch, 2007). The ways in which individuals think and feel about inequality, prior to their activities in this area, hold promise for future theory-building around inequalities, to balance the current over-stress on the structural elements of institutions (Waylen, 2014).

Our third contribution is to the specifics of the gender institution and the inequality that lies therein. We identify consciousness-raising as the fifth important element of institutional apprehension. It involves individuals 
becoming aware of their place within the larger institution of gender, and how the everyday 'doing of gender' relates to field-level policy and rules, as well as organisational regimes. Current approaches to the antecedents of institutional work argue for an 'eureka' moment in which individuals 'see' the broad institution (Suddaby et al., 2016). Our concept of CR is different as it demonstrates how individuals apprehend the broad institution and its constituent parts in synthesis. Our key argument is that the apprehension of the whole institution, its different dimensions, and the interactions between these dimensions is crucial in challenging gender inequality. This is because it's in these interactions that inequality is naturalised and replicated. Thus, whilst other studies show “moments of self-awareness" (Suddaby el al., 2016, p.229), often brought about by shocks or large-scale events (Ruebottom \& Auster, 2017), we show how that self-awareness is created in the everyday.

Consciousness-raising involves individuals connecting the gendered 'everyday' with organisational regimes and orders, and can imbue individuals with a sense of agency, or power, within institutions (Reger, 2004). Importantly, this means that individuals themselves move from a distributional understanding of power (where men hold power and can either provide or withdraw opportunities for women) to a relational understanding of power (as a process engaged in by all). Thus, $\mathrm{CR}$ and its ability to bring power and privilege into focus is key. Whilst existing studies of cognitive and emotional institutional work (Moisander et al., 2016; Voronov \& Yorks, 2015) tend to portray power as distributional, our concept of CR demands that power is better understood as relational. Relational power is an ongoing process between individuals and groups, sometimes physical, more often covert, hidden and even unconscious (Foucault, 1977). Relationality implies the opportunity for destabilising the gender status-quo (Knights \& McCabe, 1999). By adopting a feminist lens alongside institutional theory, we allow this nuance to be brought to light, since the multi-layered nature of social institutions can be closely articulated, as seen in the data.

Consciousness-raising is an important antecedent to inequality change efforts. Our data show that individuals mobilise, and perform institutional work (such as advocating for literacy programmes). What's more, the changes advocated are more likely to take in a holistic understanding of the causes of, and potential solutions to inequality, given the multi-levelled apprehension that takes place. Yet a relational approach to power and institutions also means that $\mathrm{CR}$ can induce fatalism or resistance, as individuals decide that there is little they can (or want) to do to change inequalities. Ultimately, despite experiencing CR, they may recreate the gendered status-quo. This finding reiterates the dynamic tension between institutional disruption and maintenance. However, unlike existing approaches to gender and institutional change, we do not see this as a problem of "embedded agency" (Battilana \& 
D'Aunno, 2009) whereby individuals are blind to the institutions in which they reside, or that they "lack" power (Levy \& Scully, 2007). Rather, we provide evidence that individuals can understand very well the multiple, embedded dimensions of the gender institution, and some are able to understand the ways in which these dimensions feed into one another for the continuation of inequality, and their role within this. Thus the challenge is to make clear how "the personal is political" through consciousness-raising in value chain settings, and to continuously reinvigorate change processes to avoid a fatalistic attitude to inequalities.

\section{Concluding remarks}

Extant studies of inequality in organisational and institutional settings may miss the nuanced causes and effects of inequalities, particularly when equality efforts are targeted at organisational and policy levels (Acker, 2006; Waylen, 2014). In contrast, we conceptualise and empirically study gender as the critical social institution. We identify five different elements of institutional apprehension necessary for individuals to begin to understand inequalities as byproducts of the dimensions of the gender institution. We identify CR as a synthesis of this understanding, particularly as it reveals the gendered power relations that can both replicate, and possibly undo, gender inequality.

There are some limitations to our study. First, it is well known that the empirical study of institutional work can be difficult to achieve given the need to capture practice, talk and interaction (Lawrence et al., 2009). We go further and 'dial back' to individuals' thoughts, feelings and reflections which precede work, a level of analysis which will always be refracted through their re-telling. Further, gender-related practices and reflections are notoriously difficult to measure in organisational research, given their occluded nature (Yancey Martin, 2001). Accordingly, to achieve the appropriate depth of analysis, our focus is narrow. Thus, a limitation of our paper is modest attention to intersectionality of "inequality regimes" (Acker, 2006) (for example around gender, class and ethnicity). Thus, future research could build on the concept of the gender institution by overlaying its dimensions with those of class and ethnicity.

Our narrow focus means we were unable to delve into other questions that arose during the analysis of the data. For example, are there certain backgrounds, experiences or characteristics of individuals which mean they are more likely to engage in institutional apprehension? Are there common sequences of institutional apprehension which mean individuals are more likely to engage in CR? What are the best ways to encourage individuals to take action, once they have undergone a process of CR? These all offer rich future areas of enquiry. Further, since we 
have drawn on feminist sociology's large and theoretically sophisticated body of work to show how gender inequality is multi-layered, ingrained and complex, we urge others to explore this further. Whilst the challenge of combatting gender inequality, especially in the global South continues, we have multiple opportunities to hone our tools.

Finally, we believe that our case study offers practical insights for organisations attempting to challenge inequalities, especially in value chains. First, we have shown how crucial it is to include farmers (or more broadly, the 'beneficiaries' of equality initiatives) within programme evaluations, re-design, and academic research. The use of participatory methods not only aids the 'voice' of these marginalised stakeholders, but may be one route into prompting CR with employees, suppliers, and workers in the value chain (Author 1, 2016). Second, we have indicated that for organisations to truly impact gender inequality they must expand their field of vision, to include the household and communities (and roles therein) (Author 1, forthcoming). Finally, we have shown how allowing, and encouraging, diverse stakeholders to reflect on strategies, rules, decisions and the very nature of what it is they wish to change, is productive. Making the invisible visible again is one step towards greater gender equality.

\section{References}

Acker, J. (1990). Hierarchies, jobs, bodies: A theory of gendered organizations. Gender \& Society, 4(2), 139-158.

Acker, J. (1992). From sex roles to gendered institutions. Contemporary Sociology: A Journal of Reviews, 21(5), 565-569.

Acker, J. (1994). The gender regime of Swedish banks. Scandinavian Journal of Management, 10(2), 117-130.

Acker, J. (2004). Gender, capitalism and globalization. Critical Sociology, 30(1), 17-41.

Acker, J. (2006). Inequality regimes: Gender, class, and race in organizations. Gender \& Society, 20(4), 441-464.

Alvesson, M., \& Kärreman, D. (2007). Constructing mystery: Empirical matters in theory development. Academy of Management Review, 32(4), 1265-1281. 
Battilana, J. \& D'Aunno, T. (2009). Institutional work and the paradox of embedded agency. In T. Lawrence, R. Suddaby \& B. Leca (Eds.) Institutional work: Actors and agency in institutional studies of organizations. (pp.3158). Cambridge: Cambridge University Press.

Benschop, Y. \& Verloo, M. (2011). Gender change, organizational change and gender equality strategies. In E. N. Jeanes, D. Knights, \& P. Yancey Martin. (Eds.) The handbook of gender, work \& organization. (pp.277-290). Chichester: Wiley Blackwell.

Benschop, Y. \& Doorewaard, H. (1998). Covered by equality: The gender subtext of organizations. Organization Studies, 19(5), 787-805.

Bourdieu, P. (2001). Masculine domination. Stanford: Stanford University Press.

Calás, M. B., Smircich, L. \& Holvino. E. (2014). Theorizing gender-and-organization: Changing times...Changing theories? In S. Kumra, R. Simpson, \& R.J. Burke (Eds.) The Oxford handbook of gender in organizations. (pp.1746). Oxford: OUP.

Clark, G. (1994). Onions are my husband: Survival and accumulation by West African market women. Chicago: Chicago University Press.

Connell, R. (2005). Advancing gender reform in large-scale organisations: A new approach for practitioners and researchers. Policy and Society, 24(4), 5-24.

Connell, R. W. (2009). Gender in world perspective. Cambridge: Polity Press.

Connell, R.W. (1987). Gender and power: Society, the person and sexual politics. Cambridge: Polity Press. 
Creed, W. D., DeJordy, R. \& Lok, J. (2010). Being the change: Resolving institutional contradiction through identity work. Academy of Management Journal, 53(6), 1336-1364.

Creed, W. D., Hudson, B. A., Okhuysen, G. A. \& Smith-Crowe, K. (2014). Swimming in a sea of shame: Incorporating emotion into explanations of institutional reproduction and change. Academy of Management Review, $39(3), 275-301$.

Deutsch, F.M. (2007). Undoing gender. Gender \& Society, 21(1), 106-127.

DiMaggio, P. J. (1988). Interest and agency in institutional theory. In L. G. Zucker (Ed.), Institutional patterns and organizations: Culture and environment. (pp.3-22). Cambridge: Ballinger.

Elvira, M. M. \& Graham, M. E. (2002). Not just a formality: Pay system formalization and sex-related earnings effects. Organization Science, 13(6), 601-617.

Ely, R.J. \& Meyerson, D.E. (2000) Advancing gender equity in organizations: The challenge and importance of maintaining a gender narrative. Organization, 7(4), 589-608.

Fairtrade Foundation. (2017). Where Fairtrade needs to do more. Retrieved from: http://www.fairtrade.org.uk/Whatis-Fairtrade/The-impact-of-our-work/Where-Fairtrade-needs-to-do-more.

Foucault, M. (1977). Discipline and punish: The birth of the prison. New York: Vintage Books.

Freire, P. (1970). Cultural action for freedom. Cambridge, MA: Center for the Study of Development and Social Change.

Friedland, R. (2017). Moving institutional logics forward: Emotion and meaningful material practice. Organization Studies, DOI:0170840617709307.

Gherardi, S. (1994). The gender we think, the gender we do in our everyday organizational lives. Human Relations, 
46(6), 591-610.

Gioia, D.A., Corley, K. G. \& Hamilton, A.L. (2012). Seeking qualitative rigor in inductive research: Notes on the Gioia methodology. Organizational Research Methods, 16(1), 15-31.

Gondo, M. B., \& Amis, J. M. (2013). Variations in practice adoption: The roles of conscious reflection and discourse. Academy of Management Review, 38(2), 229-247.

Greenwood, R., Suddaby, R., \& Hinings, C. R. (2002). Theorizing change: The role of professional associations in the transformation of institutionalized fields. Academy of Management Journal, 45(1), 58-80.

Grosser, K., McCarthy, L., \& Kilgour, M. (2016). Gender equality and responsible business: Expanding CSR horizons. Saltaire: Greenleaf.

Grosser, K., Moon, J., \& Nelson, J. (2017). Gender, business ethics, and corporate social responsibility: Assessing and refocusing a conversation. Business Ethics Quarterly, 24(4), 541-567.

Hochschild, A. R. (1979). Emotion work, feeling rules, and social structure. American Journal of Sociology, 85(3), $551-575$.

Huntington, S. P. (1968). Political order in changing societies. New Haven: Yale University Press.

Karam, C. M., \& Jamali, D. (2013). Gendering CSR in the Arab Middle East: An institutional perspective. Business Ethics Quarterly, 23(1), 31-68.

Kenny, M. (2007). Gender, institutions and power: A critical review. Politics, 27(2), 91-100.

Knights, D., \& McCabe, D. (1999). 'Are there no limits to authority?': TQM and organizational 
power. Organization Studies, 20(2), 197-224.

Langley, A. (1999). Strategies for theorizing from process data. Academy of Management Review, 24(4), 691-710.

Lawrence, T. B. (2008). Power, institutions and organizations. In R. Greenwood, C. Oliver, K. Sahlin, \& R. Suddaby (Eds.), The Sage handbook of organizational institutionalism (pp. 170-197). London: Sage.

Lawrence, T., \& Suddaby, R. (2006). Institutions and institutional work. In S. R. Clegg, C. Hardy, T. B. Lawrence, \& W. B. Nord (Eds.), The Sage handbook of organization studies (pp. 215-254). London: Sage.

Lawrence, T. B., Suddaby, R., \& Leca, B. (2009). Introduction: theorizing and studying institutional work. In T. B. Lawrence, R. Suddaby, \& B. Leca (Eds.), Institutional work: Actors and agency in institutional studies of organizations (pp. 1-27). Cambridge: Cambridge University Press.

Lawrence, T. B., Leca, B., \& Zilber, T. (2013). Institutional work: Current research, new directions and overlooked issues. Organization Studies, 34(8), 1023-1033.

Levy, D. \& Scully, M. (2007). The institutional entrepreneur as modern prince: The strategic face of power in contested fields. Organization Studies, 28(7), 971-991.

Lorber, J. (1994). Paradoxes of gender. New Haven: Yale.

Lueptow, L. B., Garovich-Szabo, L. \& Lueptow, M. B. (2001). Social change and the persistence of sex typing: 1974-1997. Social Forces, 80(1), 1-36.

Lukes, S. (1974). Power: A radical view. London: Macmillan. 
Mena, S. \& Suddaby, R. (2016). Theorization as institutional work: The dynamics of roles and practices. Human Relations, 69(8), 1669-1708.

Moisander, J. K., Hirsto, H., \& Fahy, K. M. (2016). Emotions in institutional work: A discursive perspective. Organization Studies, 37(7), 963-990.

Munir, K. A. (2015). A loss of power in institutional theory. Journal of Management Inquiry, 24(1), 90-92.

Nilsson, W. (2015). Positive institutional work: Exploring institutional work through the lens of positive organizational scholarship. Academy of Management Review, 40(3), 370-398.

Oliver, C. (1992). The antecedents of deinstitutionalization. Organization Studies, 13(4), 563-588.

Powell, W. W. \& Colyvas, J. A. (2008). Microfoundations of institutional theory. In R. Greenwood, C. Oliver, K. Sahlin \& R. Suddaby (Eds.), The Sage handbook of organizational institutionalism. (pp. 276 -298). London, UK: Sage.

Prügl, E., \& True, J. (2014). Equality means business? Governing gender through transnational public-private partnerships. Review of International Political Economy, 21(6), 1137-1169.

Rao, A., Sandler, J., Kelleher, D., \& Miller, C. (2016). Gender at work: Theory and practice for 21st century organizations. New York: Routledge.

Reger, J. (2004). Organizational "emotion work" through consciousness-raising: An analysis of a feminist organization. Qualitative Sociology, 27(2), 205-222.

Ridgeway, C.L. \& Correll, S. J. (2004). Unpacking the gender system: A theoretical perspective on gender beliefs and social relations. Gender \& Society, 18(4), 510-531. 
Ridgeway, C. L., \& Smith-Lovin, L. (1999). The gender system and interaction. Annual Review of Sociology, 25,191-216.

Risman, B. (2004). Gender as a social structure: Theory wrestling with activism. Gender \& Society, 18(4), 429-450.

Ruebottom, T. \& Auster, E. R. (2017). Reflexive dis/embedding: Personal narratives, empowerment and the emotional dynamics of interstitial events. Organization Studies. DOI:10.1177/0170840617709308

Ryan, B. (2013). Personal is political. In G. Ritzer (Ed.). Blackwell Encyclopaedia of Sociology. (pp.1-2). Oxford: Blackwell Publishing.

Sarachild, K. (1978). A program for consciousness-raising. In B. A. Crow (Ed.), Radical feminism: A documentary reader. (pp.273-276). New York: New York University Press.

Schwalbe, M., Godwin, S., Holden, D., Schrock, D., Thompson, S. \& Wolkomir, S. (2000). Generic processes in the reproduction of inequality: An interactionist analysis. Social Forces, 79(2), 419-52.

Seo, M. G. \& Creed, W. E. D. (2002). Institutional contradictions, praxis, and institutional change: A dialectical perspective. Academy of Management Review, 27(2), 222-247.

Sowards, S. K. \& Renegar, V.R. (2004). The rhetorical functions of consciousness-raising in third-wave feminism. Communication Studies, 55(4), 535-552.

Suddaby, R., Viale, T. \& Gendron, Y. (2016). Reflexivity: The role of embedded social position and entrepreneurial social skill in processes of field level change. Research in Organizational Behavior, 36, 225-245.

Turner, V. (1987). The anthropology of performance. New York: Performance Arts Journal Publications. 
UN Women (2015). Progress of the world's women 2015-2015. Transforming economies, realizing rights. Geneva: United Nations.

Voronov, M. \& Vince, R. (2012). Integrating emotions into the analysis of institutional work. Academy of Management Review, 37(1), 58-81.

Voronov, M. \& Weber, K. (2016). The heart of institutions: Emotional competence and institutional actorhood. Academy of Management Review, 41(3), 456-478.

Voronov, M. \& Yorks, L. (2015). “Did you notice that?” Theorizing differences in the capacity to apprehend institutional contradictions. Academy of Management Review, 40(4), 563-586.

Walby, S. (1997). Gender transformations. London: Routledge.

Waylen, G. (2014). Informal institutions, institutional change, and gender equality. Political Research Quarterly, $67(1), 212-223$.

West, C. \& Zimmerman, D. (1987). Doing gender. Gender \& Society, 1(2), 125-151.

World Bank. (2011). World development report 2012: Gender equality and development. Washington: World Bank.

Yancey-Martin, P. (2001). "Said and done" versus "saying and doing": Gendering practices, practicing gender at work. Gender \& Society, 17(3), 342-366

Yancey-Martin, P. (2004). Gender as social institution. Social forces, 82(4), 1249-1273. 


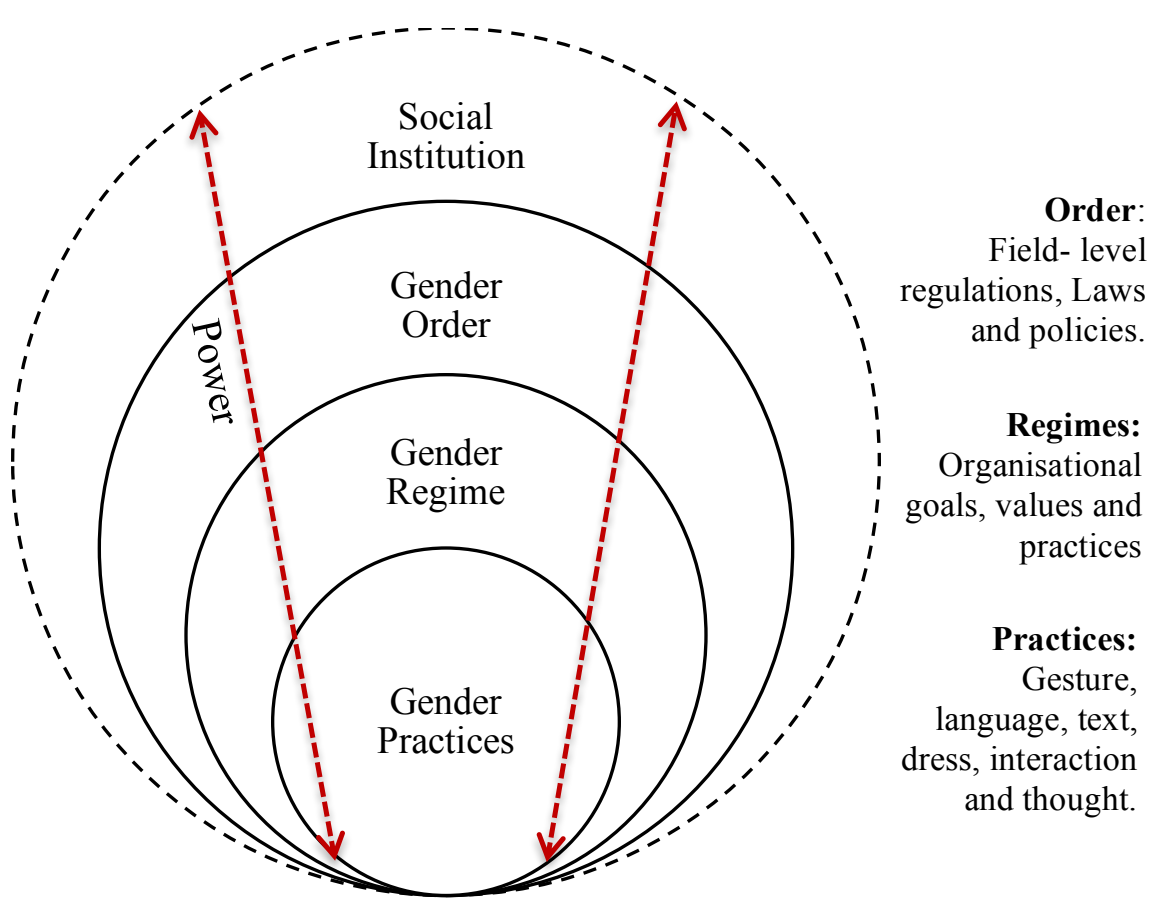

Figure 1: Dimensions of the gender institution 


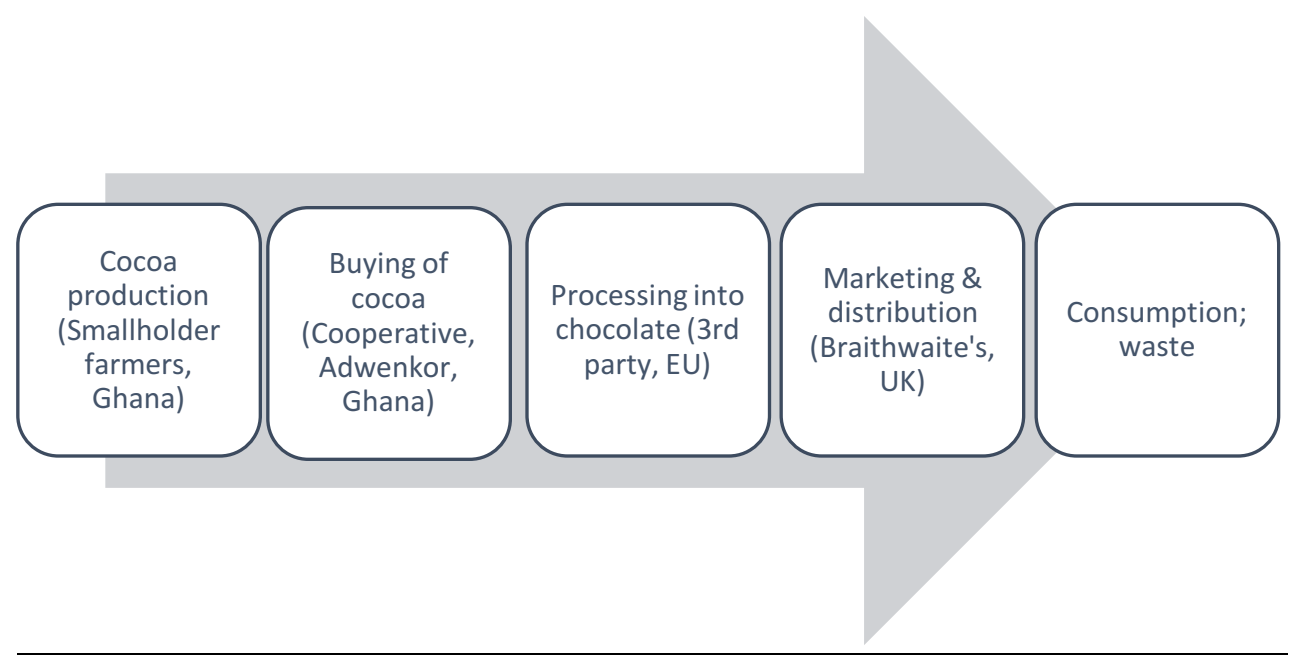

Figure Two: Case study simplified cocoa/chocolate value chain 


\section{$1^{\text {st }}$ order Concepts}

$2^{\text {nd }}$ Order Themes

- Questioning Fairtrade rules on inclusivity e.g. 'If it's not fair it's not Fair trade'

- Theorising the 'dropping off' of the gender agenda within Fairtrade e.g. 'Gaping hole in the Fairtrade narrative'

- Highlight ing unfairness of cooperative membership rules for women.

- Theorising wider societal in equalities and their impact on the success of the WFWP.e.g. 'The set up in this country is not favourable to females' - Postulating that women are not cocoa buyers due to lack of education
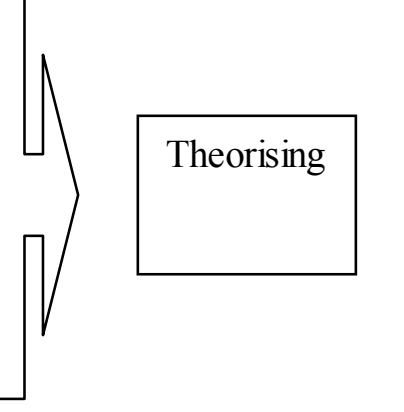

- Reflecting on lack of organisational support for WFWP e.g. 'It's nobody's business'

- Power imbalance in appointing one Gender officer, without support.

- 'Big man' culture at Adwenkor resists equality - Assumptions made over women's loyalty to other women/more 'ethical' farmers.

- Lack of female role models in Adwenkor management.
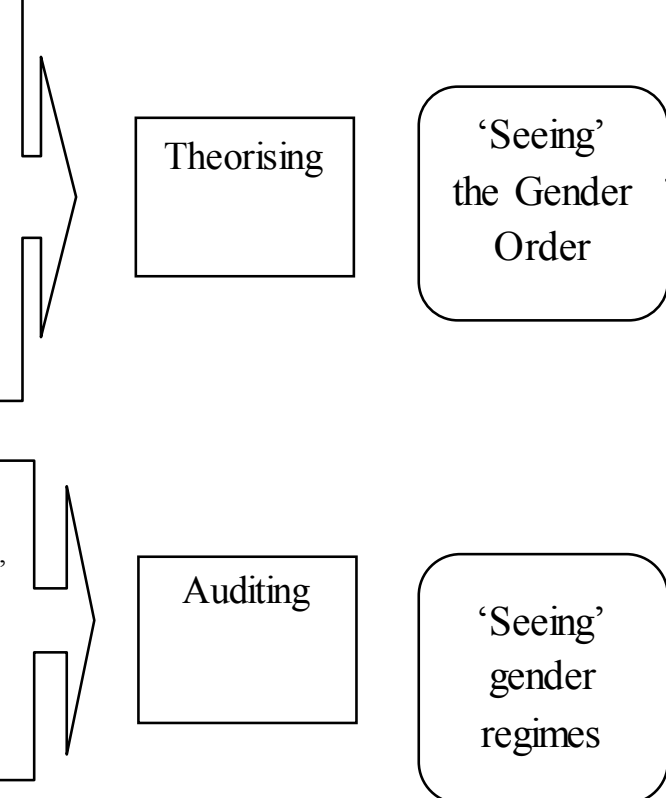

Auditing

- Exploring 'gender' through own experiences of inequality e.g. UK political party membership, sexism at work, unfair domestic workload.

- Exploring 'equality' through own experience of parenting e.g. 'My girls', 'I've got a daughter' - Referencing popular media e.g. Madein Dagenham; Lean In to draw comparisons.

- Seeing difference and inequality in tasks for men and women in the home.

- Seeing class difference: Farming women 'can do marvelous things'

- Seeing cultural differences bet ween Ghana \& UK e.g. education styles.

- Equal is seen in different ways by different people. - Difference in roles should be unchallenged: Northern intervention?

Figure 3: Data structure for gender institutional apprehension (adapted from Gioia et al., 2012). 
Table 1: Gender inequalities in the Ghanaian cocoa value chain and WFWP activities

\begin{tabular}{|l|l|l|}
\hline $\begin{array}{l}\text { Gender inequalities in the Ghanaian } \\
\text { cocoa value chain }\end{array}$ & WFWP activities & Key findings from 2013 evaluation \\
\hline $\begin{array}{l}\text { Men historically given greater } \\
\text { economic, social and political } \\
\text { opportunities than women }\end{array}$ & $\begin{array}{l}\text { Gender equality in } \\
\text { representation written into } \\
\text { supplier cooperative's } \\
\text { constitution }\end{array}$ & $\begin{array}{l}\text { Achieved. More women now in } \\
\text { leadership positions (from 3\% to 30\%). }\end{array}$ \\
\hline $\begin{array}{l}\text { Women under-represented at all levels } \\
\text { of cocoa industry (e.g. decision- } \\
\text { making, formal recognition as } \\
\text { farmers). } \\
\begin{array}{l}\text { Women face structural barriers to } \\
\text { leadership roles e.g. lack of education, } \\
\text { land. }\end{array}\end{array}$ & $\begin{array}{l}\text { Quotas for female } \\
\text { representation in } \\
\text { district and committee levels }\end{array}$ & $\begin{array}{l}\text { Partially achieved. Few exceptions at } \\
\text { village level; very few female cocoa } \\
\text { buyers. }\end{array}$ \\
\hline $\begin{array}{l}\text { Women have less formal education } \\
\text { and lower literacy than men. }\end{array}$ & $\begin{array}{l}\text { Skills training for women in } \\
\text { leadership and business skills } \\
\text { Women have less confidence and } \\
\text { Women traditionally given men. } \\
\text { responsibility for the home, which } \\
\text { reduces time to invest in other } \\
\text { activities. }\end{array}$ & $\begin{array}{l}\text { Partially achieved. However, training } \\
\text { limited to very few often from higher } \\
\text { classes who do not have full household } \\
\text { responsibilities }\end{array}$ \\
\hline $\begin{array}{l}\text { Women typically have little access to, } \\
\text { or control of, money from cocoa } \\
\text { farming. }\end{array}$ & $\begin{array}{l}\text { Launch of women's groups } \\
\text { for microcredit schemes }\end{array}$ & $\begin{array}{l}\text { Partially achieved. Service failed to } \\
\text { keep up with demand and women's } \\
\text { groups lack political standing within } \\
\text { cooperative. }\end{array}$ \\
\hline $\begin{array}{l}\text { Lack of control of cocoa income but } \\
\text { full responsibility for the household } \\
\text { means women may face greater } \\
\text { poverty, impacting on the family. }\end{array}$ & $\begin{array}{l}\text { Skills training for women in } \\
\text { alternative income generation } \\
\text { e.g. crafts }\end{array}$ & $\begin{array}{l}\text { Partially achieved. Training has not } \\
\text { resulted in economic gain for women, } \\
\text { but some evidence of confidence } \\
\text { building. }\end{array}$ \\
\hline
\end{tabular}




\begin{tabular}{|c|c|c|c|}
\hline Organisation & $\begin{array}{l}\text { Participants, identifier and } \\
\text { job role }\end{array}$ & Methods employed & $\begin{array}{l}\text { Quantity of data } \\
\text { collected }\end{array}$ \\
\hline $\begin{array}{l}\text { Braithwaite's } \\
\text { Chocolate } \\
\text { Company } \\
\text { (BCC) } \\
\text { (UK) }\end{array}$ & $\begin{array}{l}7 \text { staff } \\
\text { BCC1 (Management) } \\
\text { BCC2 (Administration) } \\
\text { BCC3 (Marketing) } \\
\text { BCC4 (Marketing) } \\
\text { BCC5 (Management) } \\
\text { BCC6 (Management) } \\
\text { BCC7 (Marketing) }\end{array}$ & $\begin{array}{l}\text { In-depth Interviews } \\
\text { Private Meeting } \\
\text { Observations } \\
\text { Public Meetings } \\
\text { Observations (2013 \& } \\
\text { 2016) } \\
\text { Primary external } \\
\text { documents }\end{array}$ & $\begin{array}{l}6.5 \text { hours } \\
8 \text { hours } \\
20 \text { hours } \\
33 \text { Documents }\end{array}$ \\
\hline $\begin{array}{l}\text { Adwenkor } \\
\text { Cooperative } \\
\text { Supplier } \\
\text { (Ghana) }\end{array}$ & $\begin{array}{l}8 \text { staff } \\
\text { AD1 (Management) } \\
\text { AD2 (Management) } \\
\text { AD3 (Management) } \\
\text { AD4 (Gender officer) } \\
\text { AD5 (CSR officer) } \\
\text { AD6 (Committee member) } \\
\text { AD7 (Committee member) } \\
\text { AD8 (Marketing) }\end{array}$ & $\begin{array}{l}\text { In-depth Interviews } \\
\text { Private Meeting } \\
\text { Observations (2013 \& } \\
2016) \\
\text { General Observations } \\
\text { (2013 \& 2016) } \\
\text { Field visits to farms (2013 } \\
\text { \& 2016) } \\
\text { Internal documents }\end{array}$ & $\begin{array}{l}6.5 \text { hours } \\
24 \text { hours } \\
48 \text { hours } \\
120 \text { hours } \\
17 \text { Documents }\end{array}$ \\
\hline $\begin{array}{l}\text { TradeFare } \\
\text { NGO } \\
\text { (UK) }\end{array}$ & $\begin{array}{l}5 \text { staff } \\
\text { TF1 (Programmes manager) } \\
\text { TF2 (Programmes manager) } \\
\text { TF3 (Administration) } \\
\text { TF4 (Board member) } \\
\text { TF5 (Board member) }\end{array}$ & $\begin{array}{l}\text { In-depth Interviews } \\
\text { Private Meeting } \\
\text { Observations (2013 \& } \\
2016 \text { ) } \\
\text { General Observations } \\
\text { External secondary } \\
\text { documents (relevant to } \\
\text { WFWP) }\end{array}$ & $\begin{array}{l}8 \text { hours } \\
16 \text { hours } \\
24 \text { hours } \\
120 \text { Documents }\end{array}$ \\
\hline $\begin{array}{l}\text { Cocoa } \\
\text { Farmers } \\
\text { (Ghana) }\end{array}$ & 152 farmers & $\begin{array}{l}8 \text { workshops ( } 2013 \& \\
2016) \text { with between } 12 \text { and } \\
20 \text { farmers in each. } \\
\text { Workshops comprised of } \\
\text { visual diagram generation } \\
\text { and group discussions }\end{array}$ & $\begin{array}{l}8 \times 3 \text { hours (Total } 24 \\
\text { discussion hours) } \\
150 \text { diagrams }\end{array}$ \\
\hline Totals: & 172 participants & & $\begin{array}{l}21 \text { hours interviews } \\
260 \text { hours observations } \\
170 \text { Documents } \\
24 \text { hours focus group } \\
\text { discussions } \\
150 \text { diagrams }\end{array}$ \\
\hline
\end{tabular}

Table 2: Case study participants by number, identifier, organisation and methods employed 


\begin{tabular}{|c|c|c|}
\hline $\begin{array}{l}\text { Further examples of consciousness- } \\
\text { raising }\end{array}$ & $\begin{array}{l}\text { How dimensions of gender institution are } \\
\text { apprehended and synthesised }\end{array}$ & $\begin{array}{l}\text { Institutional work and } \\
\text { potential outcomes }\end{array}$ \\
\hline $\begin{array}{l}\text { TF2: "Well of course women should [be } \\
\text { members]! Because they're doing most of } \\
\text { the work. It's very difficult with the co- } \\
\text { operative structure where the constitution, } \\
\text { the by-laws, state that to be a member } \\
\text { you have to have land. It's the old } \\
\text { chestnut, isn't it? That to be recognised } \\
\text { you have to have assets. And women } \\
\text { don't, on the whole, have access to assets. } \\
\text { Many of them don't even know that they } \\
\text { are entitled in law to do so. Most } \\
\text { countries in Africa now have laws, or } \\
\text { policies, that give women, if not exactly } \\
\text { equal rights, certainly rights to own } \\
\text { property and land, buildings and } \\
\text { businesses and so on. But when you get } \\
\text { out into the rural areas very often } \\
\text { traditional ways of doing things prevail. } \\
\text { And if a woman has pretty much no } \\
\text { education..." }\end{array}$ & $\begin{array}{l}\text { TF2 recognises the nature of the cooperative } \\
\text { constitution and by-laws and how they relate to } \\
\text { women's representation ('Auditing' the gender } \\
\text { regime). } \\
\text { She discusses gendered laws around access to } \\
\text { land ('Theorising' the gender order). } \\
\text { 'Traditional ways of doing things' and 'education' } \\
\text { of individual women are acknowledged as source } \\
\text { of continuing inequality ('Exploring Difference'- } \\
\text { 'Seeing' Gender practices). } \\
\text { TF2 apprehends multiple dimensions of the } \\
\text { gender institution, and power relations therein. } \\
\text { Power is understood not just as relative to the } \\
\text { State (e.g. 'laws') but also present in the co- } \\
\text { operative structures and local traditions. }\end{array}$ & $\begin{array}{l}\text { TF2 continues to } \\
\text { commission research into } \\
\text { gender in value chains } \\
\text { (Internal Document, } \\
\text { 2016). She also sits on } \\
\text { multiple boards and } \\
\text { advocates on multi- } \\
\text { dimensional solutions to } \\
\text { gender equality (TF2, } \\
\text { 2014). }\end{array}$ \\
\hline $\begin{array}{l}\text { BCC5: 'I think it's disgraceful that } \\
\text { people are not treated equally. That's why } \\
\text { the quotas are so good. To make it equal." } \\
\text { "I do most of the cooking. My children } \\
\text { might grow up assuming that it's a man's } \\
\text { job... Now that might not be the norm, but } \\
\text { that's how they would see it. And so how } \\
\text { does that impact what we're trying to do } \\
\text { with equality? [In] our society...it'd } \\
\text { [cooking]....be expected to be the } \\
\text { woman's job. But what I'm saying is that } \\
\text { I don't want them growing up with the } \\
\text { assumption that, if my girl was to get } \\
\text { married for example, just to assume that } \\
\text { the husband was going to prepare the tea }\end{array}$ & $\begin{array}{l}\text { BBC5 started his interview highlighting the need } \\
\text { for WFWP quotas ('Auditing' the gender regime). } \\
\text { Later he turns to 'relating to others' through a } \\
\text { discussion of the cooking practices in their own } \\
\text { home, and how this might lead to stereotypes } \\
\text { ('Seeing' gender practices). BCC4 connects } \\
\text { 'norms' to the gender programme at Adwenkor: } \\
\text { 'So how does that impact what we're trying to do } \\
\text { with equality?' } \\
\text { He apprehends how 'society' involves gendered } \\
\text { assumptions, but everyday gendered practices (i.e. } \\
\text { the subversion of traditional roles) can run contra } \\
\text { to this (seeing the gender order). }\end{array}$ & $\begin{array}{l}\text { BCC5 was supportive of } \\
\text { widening the WFWP } \\
\text { focus from quotas } \\
\text { (policy-level change) to } \\
\text { literacy and education } \\
\text { (practice level change) at } \\
\text { Adwenkor. He lobbied } \\
\text { for financial aid for the } \\
\text { literacy programme, } \\
\text { which began in } 2015 \text {. }\end{array}$ \\
\hline
\end{tabular}




\begin{tabular}{|c|c|c|}
\hline $\begin{array}{l}\text { every night... it would be wrong for my } \\
\text { daughter to assume that that would be the } \\
\text { case, or for my son to assume that he had } \\
\text { to fulfill that responsibility!" (BCC5) }\end{array}$ & $\begin{array}{l}\text { BCC5 thus experiences CR as a synthesis of } \\
\text { apprehending the dimensions of the gender } \\
\text { institution. His understanding of gendered power } \\
\text { moves from one related to structure and regulation } \\
\text { (quotas) to the cultural assumptions around } \\
\text { domestic work. }\end{array}$ & \\
\hline $\begin{array}{l}\text { AD8: “I think the social setup in the } \\
\text { country is not favourable to females. The } \\
\text { man is seen as the head of the home and } \\
\text { he becomes a dictator... You see, here in } \\
\text { our part of the world - now I think of it, } \\
\text { its men who... We both work, but as a } \\
\text { man, I'll have acquired the land, but it's } \\
\text { both of us [men and women], tilling the } \\
\text { land. But when the income comes, it's the } \\
\text { man who is managing it.... We have to } \\
\text { educate their [women farmers'] husbands } \\
\text { very much here. We have to make them } \\
\text { understand that, if their wives are } \\
\text { empowered, it's in their benefit. So they } \\
\text { should be willing to assist their wives in } \\
\text { the house chores, and - but I don't know, } \\
\text { in our tradition nowadays we men don't } \\
\text { want to do house help. Our society and } \\
\text { education is designed as such." }\end{array}$ & $\begin{array}{l}\text { AD8 examines the gendered work practices of } \\
\text { men and women cocoa farmers ('exploring } \\
\text { difference'). } \\
\text { He then reflects on the need to revise the approach } \\
\text { to gender programming by 'educating' men to } \\
\text { share house hold work, and by reducing } \\
\text { childbearing. This shows linkages between } \\
\text { awareness of gender regimes and practices. } \\
\text { However, AD8 also questions whether this is } \\
\text { possible since 'tradition' and 'society' may be } \\
\text { barriers to men helping in the home. } \\
\text { Consciousness-raising takes place as the micro, } \\
\text { meso and macro levels of the gender institution } \\
\text { are linked together in the discussion of gender } \\
\text { equality in the cocoa value chain. Gendered power } \\
\text { relations are understood to lie in each of the } \\
\text { dimensions, and could be challenged at the } \\
\text { practice level, although AD8 doubts the success of } \\
\text { this. }\end{array}$ & $\begin{array}{l}\text { AD8 did not outwardly } \\
\text { appear to engage in any } \\
\text { further work towards } \\
\text { gender equality at } \\
\text { Adwenkor. }\end{array}$ \\
\hline
\end{tabular}

Table 3: Further examples of consciousness-raising and outcomes from the data 